\title{
From Baskets to Bodies: Innovation Within Aboriginal Fibre Practice
}

\author{
By Christiane Keller
}

Dr Christiane Keller is an anthropologist, art historian and writer. She was awarded a PhD from the Australian National University (Creativity and Innovation in Contemporary Rembarrnga Sculpture in the Maningrida Region, Central Arnhem Land, 2007) and MA in anthropology and art history from the Albert- Ludwigs University in Freiburg, Germany (Aboriginal Art in Daly River: Painting and its Reception in the Australian Artworld, 1999).

Christiane has worked within the fields of academia and museums. As curator at the Western Australian Museum she worked on a number of permanent and temporary exhibitions. She currently holds an Honorary Research Fellowship at the University of Western Australia, and is Research Associate at the Western Australian Museum. Her research interests encompass Indigenous art and aesthetics with a focus on sculpture, fibre art and fashion.

\begin{abstract}
This essay is concerned with the emergence of Indigenous fibre sculpture, a movement within contemporary Australian Aboriginal art. Here I discuss the work of key practitioners including Lena Yarinkura, Marina Murdilnga and Anniebell Marrngamarrnga from Central Arnhem Land; Yvonne Koolmatrie and Treahna Hamm from the Murray River region; the Central Desert artists Kantjupayi Benson, Ivy Hopkins, Jean Burke and the Utopia artists.
\end{abstract}

Many of these fibre artists developed their sculptural forms through mastering and combining long practised techniques while simultaneously pushing the boundaries of material and form. I argue that it is the urge of fibre artists to bring their connection to country, cultural heritage and contemporary life into the foreground of their artistic practice that has led them to the sculptural form. Making fibre sculpture allows the artists to pass on cultural knowledge and skills and in doing so helps to ensure the sustainability of their cultures and local economies.

I also argue that 'going sculptural' has helped re-position Aboriginal fibre art in the art market and its re-evaluation as fine art; an important step toward establishing a sustainable art practice within the wider art market.

\section{Re-positioning fibre}

Since Aboriginal art conquered the national and international art market it has diversified enormously and artists have explored new forms, techniques and 
materials to create exciting and innovative work. This has also been the case within the genre of Aboriginal fibre art where the production of fibre sculpture is a very recent development.

This essay is not about the art versus craft debate and while many authors, in particular, Morphy $(2005,2008)$ and Myers $(2002)$ have written extensively about the history of recognition of Aboriginal art as 'fine art' I will only briefly outline the key issues that helped reposition Indigenous fibre works from craft into art. As Grace Cochrane so eloquently wrote about the crafts in Australia and New Zealand: 'In the last fifty years, the benchmark for success in the crafts has been primarily in their acceptance as art' (Alfoldy 2007, p.63).

Many factors contributed to the repositioning of Aboriginal fibre in the art market. These include Government funding to set up art centres, employment of art professionals as well as artist training and exchange which became available in the 1970s. Regular marketing outlets and feedback from the art market helped Aboriginal artists to adapt their skills to make more marketable products. At the time Aboriginal art was mainly a male domain, the world of painting. The work of women was still relegated to the craft corner but over time an increasing number of female art professionals and women's centres targeted what has since become the almost exclusively female domain of fibre art.

A critical contribution was the skilful marketing of fibre art through fibre exhibitions with accompanying publications including Maningrida: The Language of Weaving (1989), Spinifex Runner (1999) and most recently Twined Together (2005). ${ }^{1}$ Several curators consciously placed fibre objects next to the representations of these objects in paintings to highlight the ancestral link many fibre objects have. Furthermore, the establishment of extensive collections held by leading art museums such as the Museum of Contemporary Art (MCA) in Sydney and the Queensland Art Gallery in Brisbane helped promote fibre work in a fine art context. Equally important was the inclusion of Aboriginal fibre art in national art awards, such as the National Aboriginal and Torres Strait Islander Arts Award (NATSIAA), and the development of public art projects in which fibre art is translated into more durable media such as cast metal or wood. Outstanding examples are the Walama Forecourt (2000), a collaboration between Judy Watson and Maningrida fibre artists, and The Grand Veranda at the Darwin Entertainment Centre (2007) with a fish trap design by James lyuna and Melba Gunjarrwanga.

But what I think contributed most to the re-evaluation of Aboriginal fibre art as fine art were the artists themselves. Their constant explorations and innovations

1 A number of other all fibre exhibitions have also taken place. Some included Indigenous and nonIndigenous artists such as Seven Sisters: Fibre Works Arising from the West (2003 touring), Woven Forms (2006 touring), Recoil: Change and Exchange in Coiled Fibre Art (2008 touring). Others did not have an extensive exhibition catalogues, including Two Countries, One Weave (1991, Tandanya Aboriginal Cultural Institute, Adelaide), Kunmadj Rowk: Contemporary Weaving from Maningrida (1993 touring) and Maningrida Threads (2003, MCA, Sydney). 
and the creation of new forms and genres have provided the crucial step. The venture into the sculptural has been significant and will be retraced for three regions in the following sections.

\section{Fibre artists 'going sculptural'}

Today Aboriginal fibre sculpture can be found in every Australian state either produced by individuals or groups of artists. To highlight the major developments within this movement I have selected a number of key artists from three main regions; Arnhem Land, the Murray River region and the Western Desert. For all of the fibre artists mentioned here, innovation is not only a response to the art market's need for continuously new and exciting works, but an important translation of their cultural heritage into contemporary art objects.

All fibre artists discussed in this paper first learned to make functional items including baskets, nets, bags, fish traps and other objects either indigenous or introduced to their culture. Once they comfortably mastered the employed techniques they managed to create the space for more innovative work. Playfully experimenting with existing forms the artists always pushed the limits of materials and techniques to turn a basket into a full-bodied sculpture or to transform a coiling technique into a more loose and free cobbling ${ }^{2}$ one, enabling the unencumbered modelling of the sculptural body. The artists are driven by the urge to depict their important stories and personal life experiences, both fuelling the ideas and energy for new creations.

\subsection{Central Arnhem Land}

Aboriginal people from all twelve language groups living in the Maningrida region of Central Arnhem Land have a strong tradition of producing a great variety of fibre based objects, most of which are used for hunting, fishing and gathering. Arnhem Land, however, is also known for its mostly bound paperbark sculptures used as ceremonial effigies which have provided inspiration for contemporary sculptures sold on the national and international market. Maningrida is today known for its two distinct schools of fibre sculptors that have developed their own styles despite depicting similar subject matters.

\subsection{Rembarrnga school of fibre sculpture}

Some ceremonial sculptures in Arnhem Land are made in a binding technique in which a core of grass or paperbark is bound with bark fibre or fibre string to form the object's body (Emu, n.d., Plate 1). During the ceremony the dancer, whose body decoration matches that of the emu sculpture, is holding the sculpture and

2 The term 'cobbling' was coined by Nalda Searles and describes the 'feral' cobbling material together with rough stitches. She sometimes also calles it 'mongrel stitch' (West 2007a: 41, 73). 
at some point both become the emu ancestor itself (Plate 2). These sculptures usually depict animals, birds, plants like yam, or spirits. Ronald Berndt recorded such spirit figures in 1949 as djondjon, representations of human-like spirits with one long and one short arm. ${ }^{3}$ They were left at an abandoned camp site, their long arm indicating the direction in which the family group had moved on. Djondjon figures might have been the inspiration for modern versions of human and spirit representations.

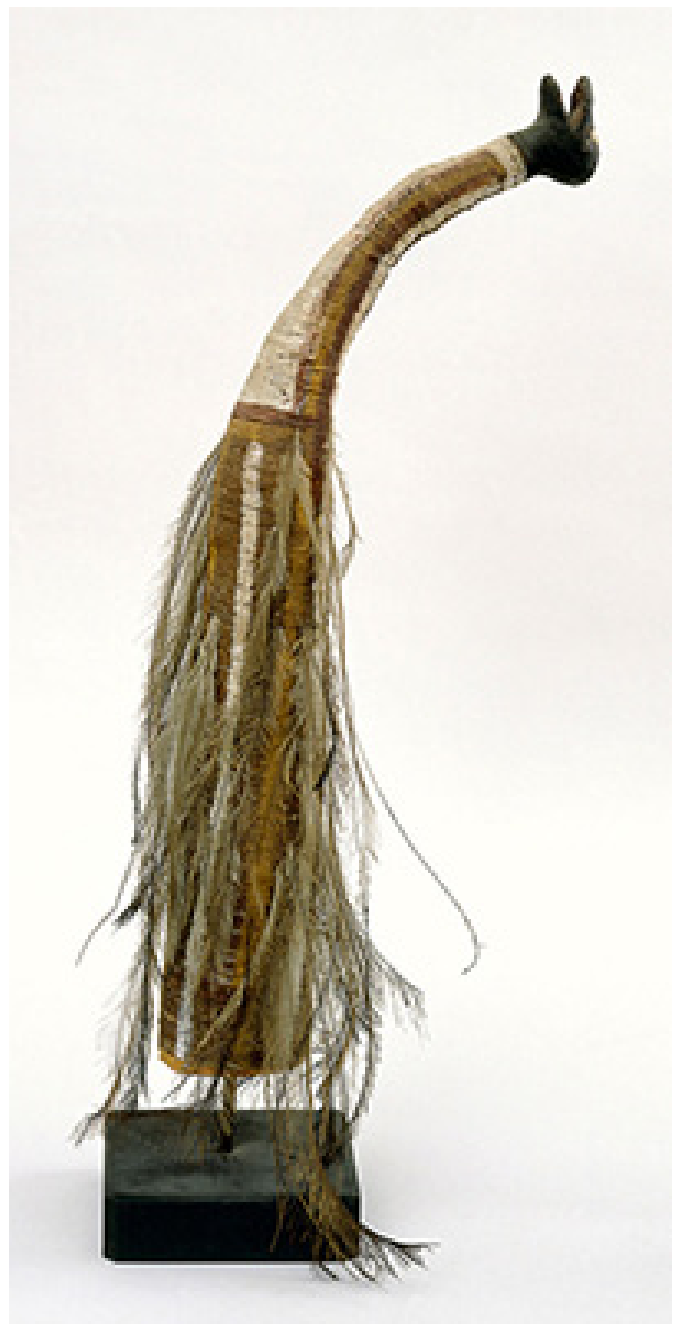

Plate 1: Artists unknown, Totemic Emblem (Emu), ca. 1950s, paperbark, fibre string, beeswax, feathers, natural ochres, $546 \times 76 \times 76 \mathrm{~mm}$

Photo: courtesy of Art Gallery of New South Wales (Purchased 1962, AGNSW \#A25).

3 Such figures were collected by Ronald Berndt in western and eastern Arnhem Land, for images see Berndt et al. 1980: 14. 


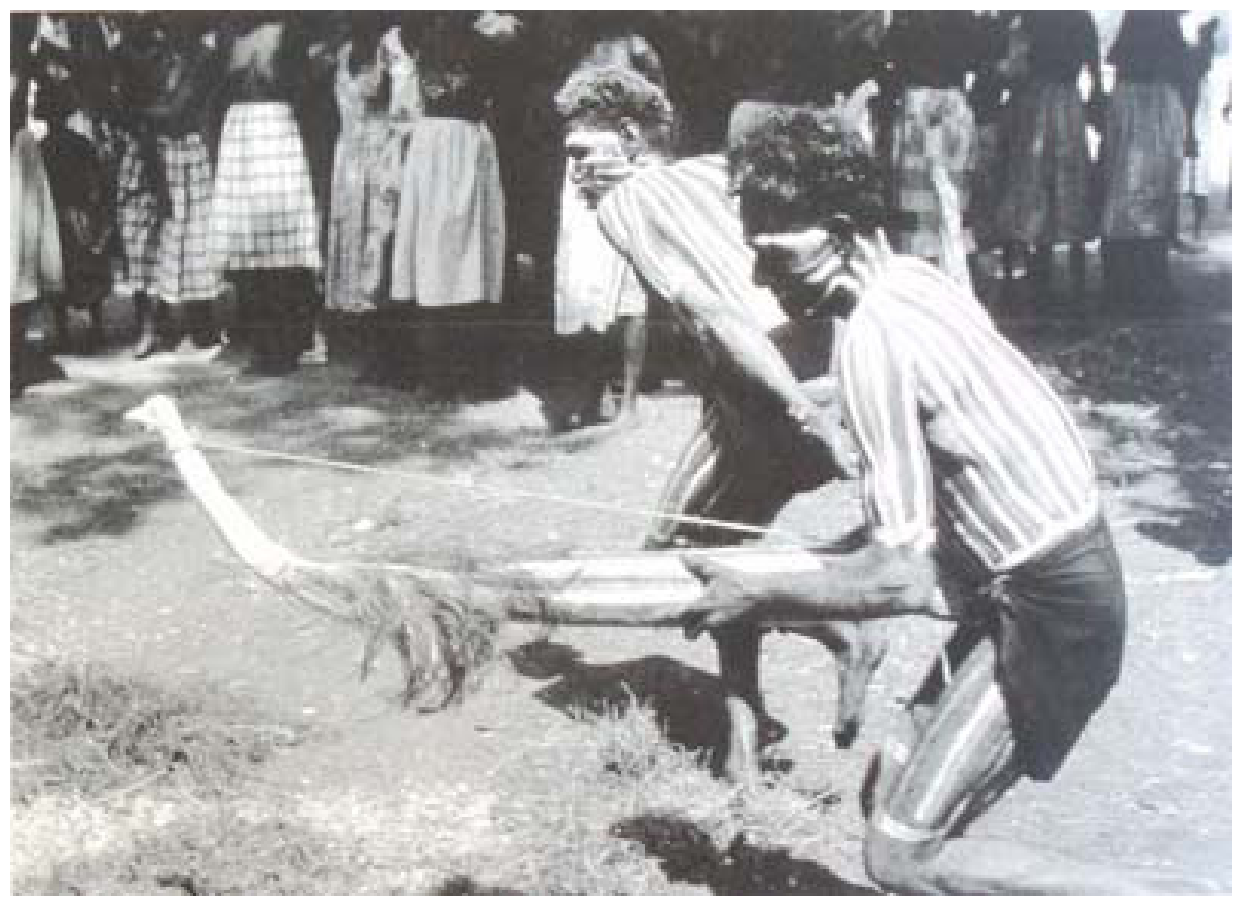

Plate 2: Two men dancing with an emu paperbark sculpture in Millingimbi, ca. 1960s

Photo: courtesy of Alan Fidock@.

In 1994 Kune artist Lena Yarinkura and Rembarrnga artist Bob Burruwal first experimented with this well-known technique of binding cores of paperbark with string or bark fibre. Family Drama, $1994,{ }^{4}$ was the first of many to come (Plate 3). This sculpture group of four humans, a dog and a burial platform reenacts a traditional burial. Then Maningrida's arts advisor Diane Moon fostered Yarinkura's artistic talent as a bark painter and fibre artist and recognised her potential as a sculptor. ${ }^{5}$ Moon reminisces about these early years:

4 In the same year Family Drama won the Wandjuk Marika Three-dimensional Award in NATSIAA and is now held by the Museum and Art Gallery of the Northern Territory (MAGNT).

5 In 1988, Yarinkura, together with her sister in law Dorothy Galaledba, was one of few women who painted in their own right. In the same year, Moon secured a Professional Development Grant from the Aboriginal Arts Board for Yarinkura to develop a solo show of her bark paintings. While the solo show at Hogarth Gallery in Sydney did not eventuate Yarinkura's work was included in a Rembarrnga group exhibition that year. 


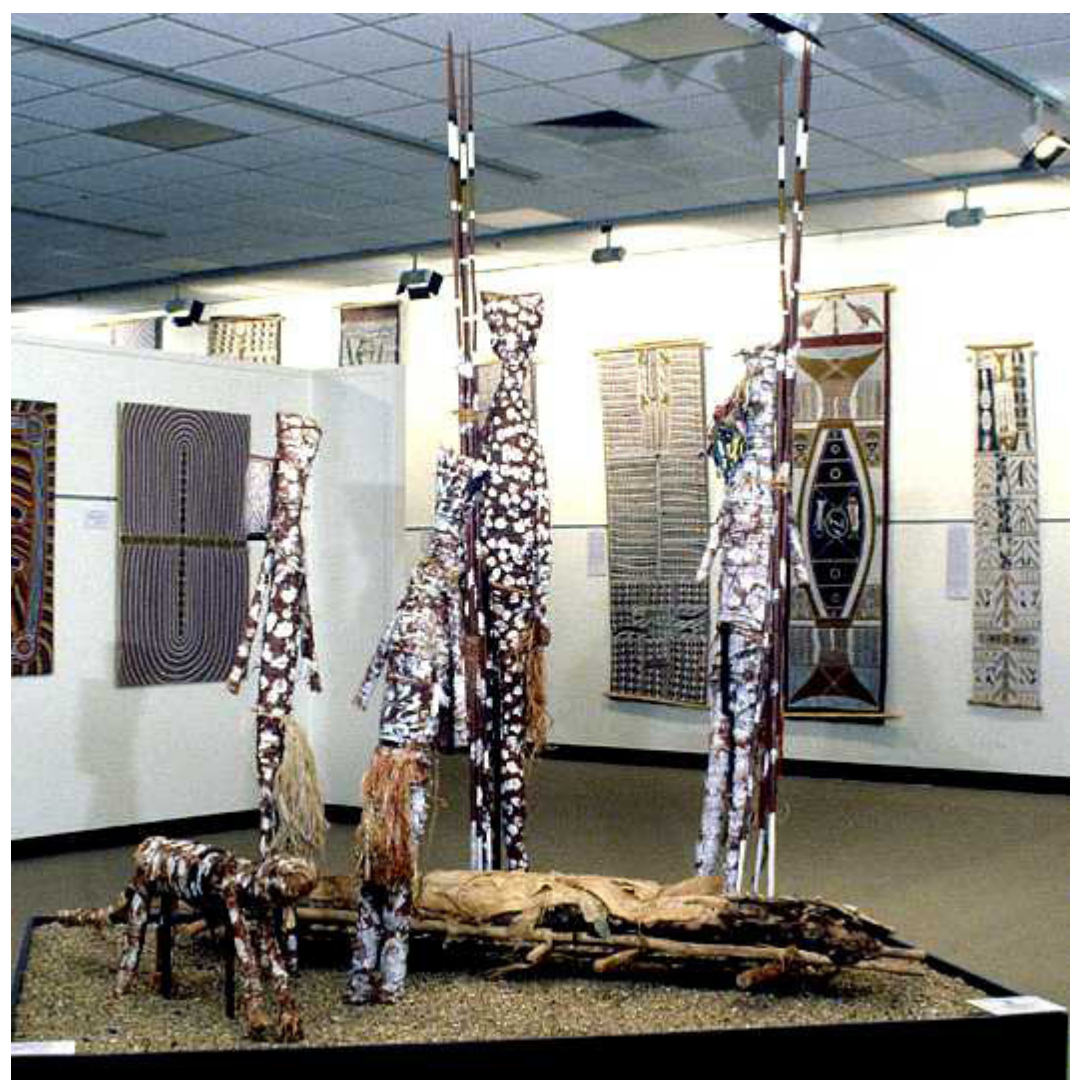

Plate 3: Lena Yarinkura and Bob Burruwal, Family Drama, 1994, paperbark, wood, fibre, natural ochres and PVA glue, life size.

Photo: courtesy of Museum and Art Gallery of the Northern Territory (Lena Yarinkura@ and Bob Burruwal@, MAGNT \#ABETH-3116 A-L).

....at that time she was mainly making the dance belts... and she had one or two for me to pick up or to come and look at it at Buluhkaduru. And when we got out there she had hung one in the curve of the bark shelter... Just the way she had hung it, the way she had....arranged it.... I just had a feeling...that she had such a sense for sculpture and architecture...and ways of arranging space. ...I remember just saying to her, keep making anything you want, just whatever you think of. Let's make it and leave the rest to me. And eventually she did start doing that. ...I think that resulted in that first sort of family that won the art award. The Mimih family ${ }^{6} \ldots$ everybody was thinking I was crazy. I remember, as I was loading it on the plane [which was very difficult]... But we did get it on the plane and it won in the Art Award. And I think she hasn't looked back since. (Moon 2003, pers. com., 8th October)

With the success of the sculpture at the most prestigious national Indigenous art prize a new category of contemporary Aboriginal fibre sculpture was

6 This sculpture group is the above mentioned Family Drama, 1994 held in the MAGNT collection. 
born. Yarinkura and Burruwal were encouraged by Moon's understanding of her role as art adviser to actively foster new artists and innovative ideas and, if necessary, find or create a market for the results (Moon 1993, p.80). They produced a second narrative sculpture group Modjarrki, Two Brothers and the Crocodile (1995) exhibited in the 1995 Australian National Heritage Art Award in Canberra and now held by the Art Gallery of NSW (AGNSW). Burruwal continues to produce similar sculptures representing spirits of his country like Wurum and Namarroddo.

Yarinkura moved on to experiment with her knowledge as a prolific fibre artist well versed in making dilly bags and fish traps. She used the technique of twining pandanus fibres to construct the bodies of her next sculpture group Ngayang Spirit, 1996 (Plate 4), consisting of two human-like sculptures and a twined mat. She began the figure like a fish trap with a wide opening into which she sewed carved wooden heads. The bodies of the spirits were stuffed with paperbark and painted with ochres.

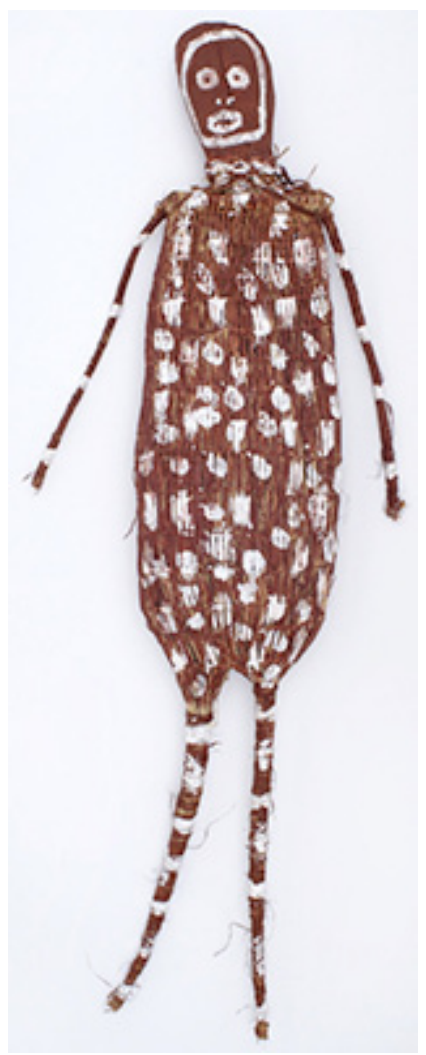

Plate 4: Lena Yarinkura, part of sculpture group Ngayang Spirit, 1996, pandanus, paperbark, wood, natural ochres and PVA glue, life size. 
She refined her technique and started the next sculptures like a conical basket or dilly bag which then extended and retracted in diameter to shape the Yawkyawk bodies of her acclaimed Family of Yawkyawk, 1997.7'As can be seen in one of her later Yawkyawk, 2009 (Plate 5), the flat fin of the half-human, halffish spirit is constructed with a technique used in twined pandanus mat-making. This combination of round and flat twining techniques within one sculpture now forms the core of Yarinkura's sculptural work. She also makes dogs, all sorts of bush animals and spirits, and combines them in sculpture groups narrating traditional bush and hunting stories as well as local myth.

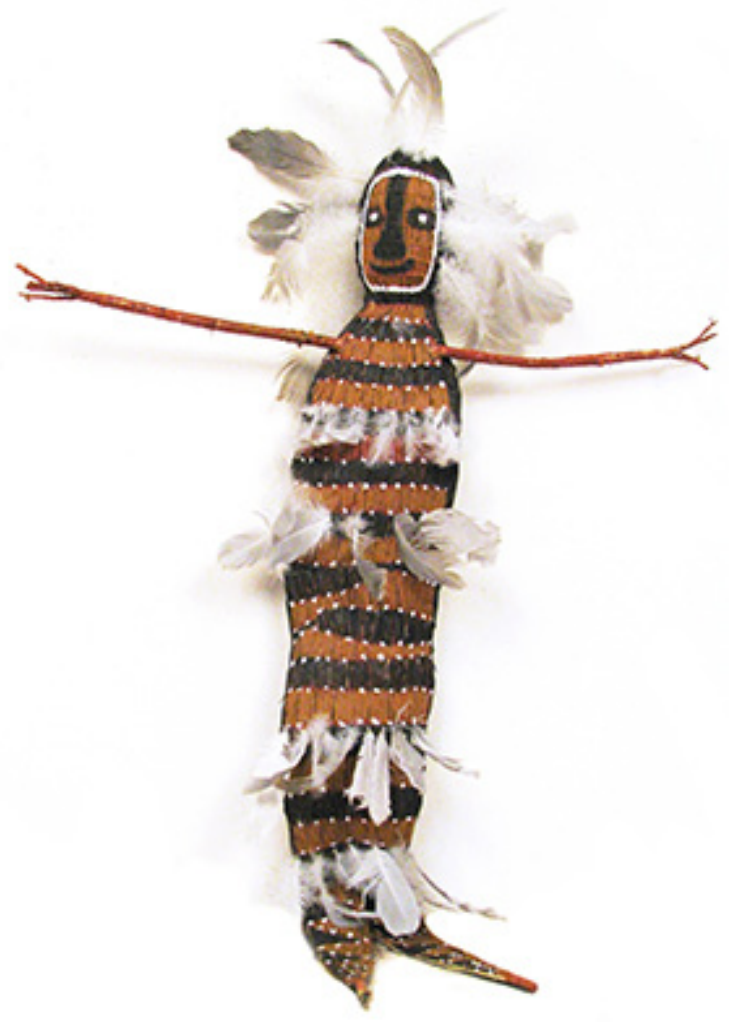

Plate 5: Lena Yarinkura, Yawkyawk, 2009, pandanus, paperbark, natural ochres and PVA glue, $1180 \times 150 \mathrm{~mm}$.

Photo: courtesy of Maningrida Arts \& Culture (Lena Yarinkura@).

For almost ten years Yarinkura and her immediate family were the only ones to practise this kind of fibre sculpture. Yarinkura's creation of this genre is widely acknowledged within the local and art arena. She is happy to share her techniques but insists that people should represent their own culture and spirits.

7 Again the Family of Yawkyawk won the 1997 NATSIAA Wandjuk Marika Three-dimensional Award and can be seen in West 2000: 93. 
Since 2003 the techniques and sculptural forms Yarinkura invented have spread, first to other Rembarrnga and Kune practitioners and then across the Arnhem Land region (Plate 6). ${ }^{8}$

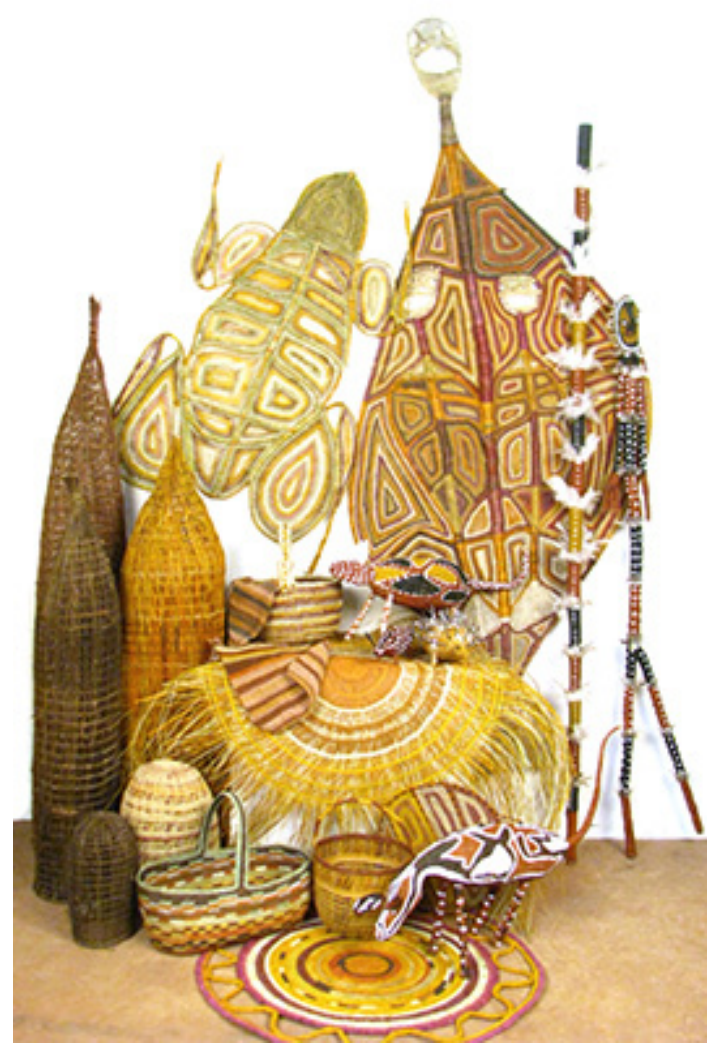

Plate 6: Collection of fibre work by Maningrida artists, 2010.

Photo: Clair Summers, courtesy of Maningrida Arts \& Culture (Maningrida artists@).

\subsection{Kuninjku school of fibre sculpture}

Kuninjku women have developed their own idiosyncratic form of fibre sculptures. Artist Marina Murdilnga, daughter of renowned bark painter Mick Kubarrku, was taught by her mother how to work with fibre. She accomplished proficiency in a number of different techniques over the years. In 2003 she invented a new

8 Some other Arnhem Land fibre artists, like Penny Ashley from Gapuwiyak, have ventured into making twined pandanus fibre. Although, Ashley sometimes resides with extended family members in Maningrida, she has no direct contact with Yarinkura or other Rembarrnga sculptors. She made a twined pandanus sculpture titled China Man, 2004, that was shown at the NATSIAA exhibition in 2004. Elizabeth Djutarra and Robyn Djunginy also need to be mentioned from the Ramingining region. Both have developed their own idiosyncratic sculptural forms. Djutarra is well-known for her yam sculptures made of string bound paperbark (included in the bundle of yam to be seen in Mundine et al. 1999: 204) and Djunginy for her twined pandanus bottles (West 2007a: 54f). 
form of flat fibre sculptures employing a knotting technique used when making string bags and butterfly fishing nets. For her first Yawkyawk sculpture she made a frame from native jungle vine creating a fin, a protruding main body, a slender neck and a head. She filled the spaces with knotted pandanus that was subsequently painted with contrasting ochre colours. Her second Yawkyawk sculpture features dyed pandanus fibres. Kuninjku women have long been acknowledged for the vibrant colours they produce using local roots, berries, leaves and barks. Murdilnga also added feathers representing the typical algaelike hair of these spirits.

Murdilnga's second Yawkyawk sculpture was entered in the 21st NATSIAA which triggered an enormous demand for this new work. She has not only made Yawkyawk spirits but ventured into interpretations of Dreaming sites in her country, such as Dirtbim, 2008 (Plate 7). Several other Kuninjku fibre artist took up this genre, among them Lulu Laradjby, Frewa Bardaluna and most prominently Anniebell Marrngamarrnga, together creating the Kuninjku school of fibre sculpture. Marrngamarrnga has brought the art form to new heights through the vibrant colours circulating within each section of the body and the increase of scale, complexity and intricacy (Plate 8). ${ }^{9}$

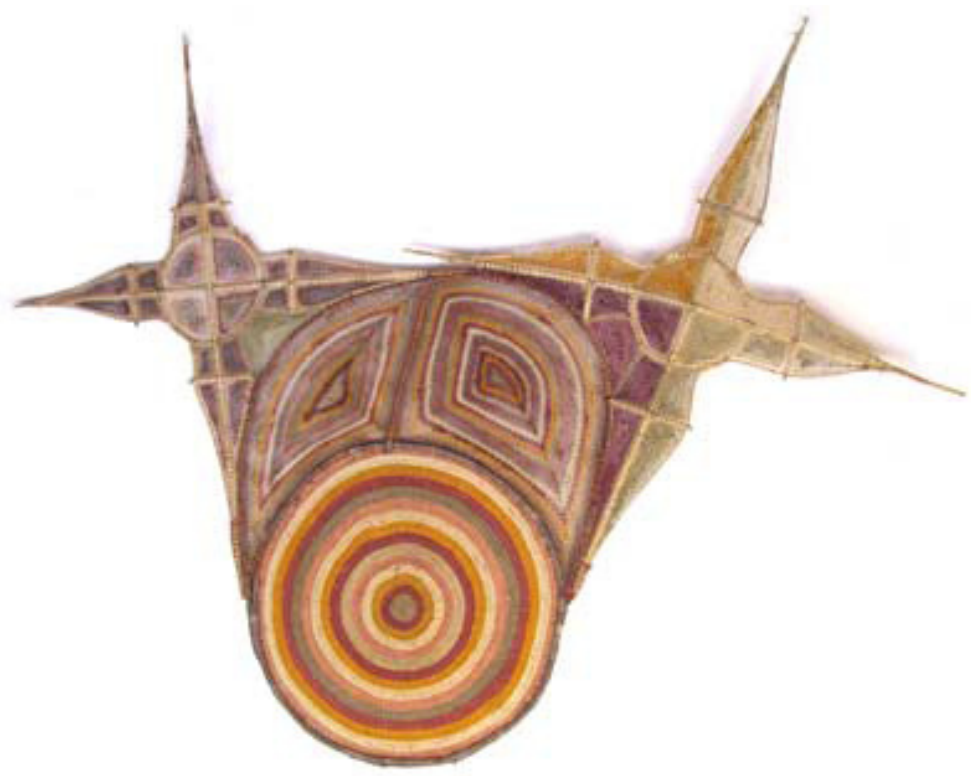

Plate 7: Marina Murdilgna, Dirtbim, 2008, bamboo, natural dyed pandanus. 1890 x $1440 \mathrm{~mm}$.

Photo: courtesy of Maningrida Arts \& Culture (Marina Murdilgna@).

9 Marrngamarrnga was the only fibre artist chosen to exhibit in the National Gallery of Australia's inaugural National Indigenous Art Triennial touring exhibition in 2008. 


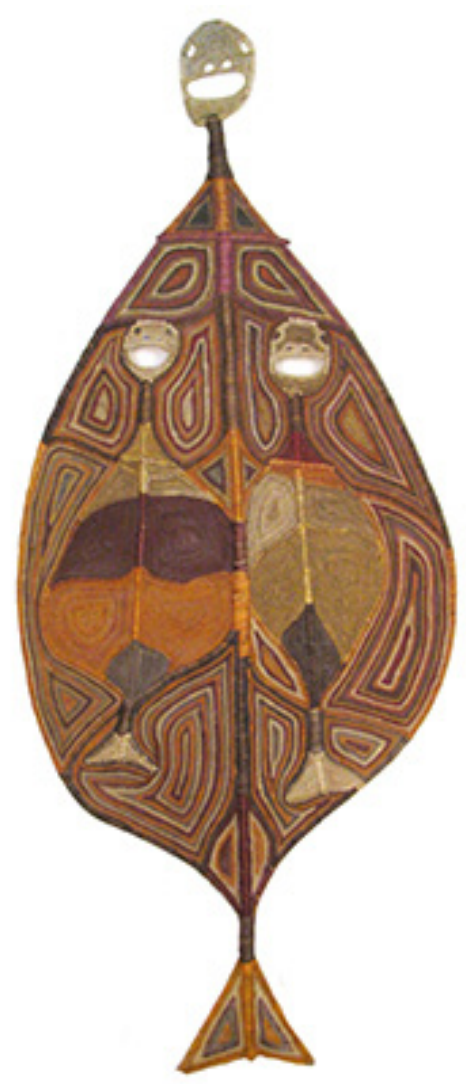

Plate 8: Anniebell Marrngamarrnga, Yawkyawk with Baby Twins, 2010, bamboo, natural dyed pandanus. $2320 \times 965 \mathrm{~mm}$.

Photo: courtesy of Maningrida Arts \& Culture (Anniebell Marrngamarrnga@).

Yawkyawk play an important role in the Maningrida region with seven different Yawkyawk dreaming sites spread across a number of language groups. Both Rembarrnga and Kuninjku artists represent Yawkyawk from their clan lands. Yarinkura features Yawkyawk from billabongs near Bolkdjam and Goernoejangga and some Kuninjku women represent the Yawkyawk who are present at Kubumi, a waterhole close to the outstation where they live and work. While particular fibres and the locations at which they grow have strong links to the Yawkyawk complex, the connection between traditional baskets, string bags and fish nets made from these materials and the Yawkyawk complex was rather obscure. Through physically representing the Yawkyawk spirit in innovative sculptural fibre objects this connection has been brought to the forefront.

Not only techniques have spread across families and country all the way to Oenpelli, but the range of subject matter has increased as well. Freshwater crocodiles, butterflies and even representations of Dreaming sites are now also on the market. Close family links and intermarriage between different clans and language groups allow artists to share these innovative ideas and develop them 
further, as can be seen in Butterfly, 2006 (Plate 9), by Sylvia Brown. Brown has combined both the Rembarrnga and Kuninjku techniques of twining pandanus in the round and knotting pandanus within a flat framework.

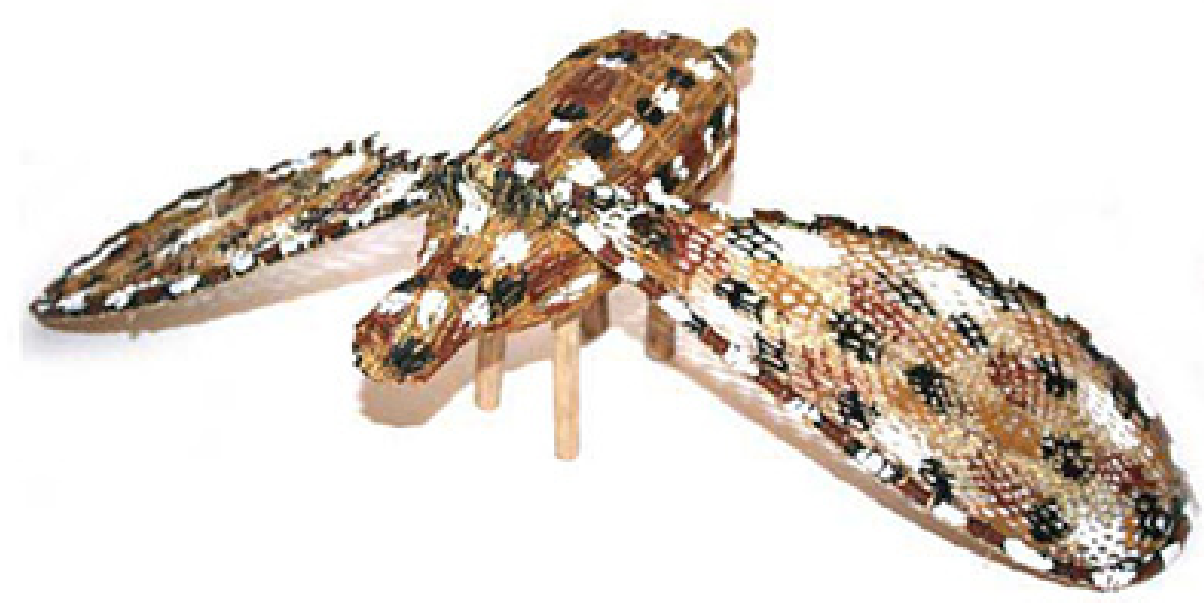

Plate 9: Sylvia Brown, Butterfly, 2008, unidentified wood, pandanus fibre, paperbark and natural ochres with PVA glue, $300 \times 470 \times 150 \mathrm{~mm}$.

Photo: courtesy of Maningrida Arts \& Culture (Sylvia Brown@).

Aboriginal artists travel to the major cities or overseas to see their work in exhibitions and have exposure to the reception of their own work as well as that of other artists. Although they actively engage with a world that has changed rapidly since European settlement their own cultural codes are overall intact and active. This means that some work is restricted and cannot be seen by uninitiated audiences, especially if it is used in secret-sacred ceremonies. Thus, for artists to make products for an all encompassing art market where Indigenous cultural rules of restriction cannot be enforced or monitored, they needed to extend their artistic practice.

As I have extensively discussed elsewhere (Keller 2007, chapter 7), until 2004 Rembarrnga artists produced the broadest variety of sculptural forms within the Maningrida region. This included carved wooden sculptures and a whole range of fibre sculptures made from paperbark, bark fibre, string, grass and pandanus fashioned in a range of techniques including binding, twining and knotting. Unfortunately, the constraints of this essay do not allow me to discuss Rembarrnga work in detail. However, in my earlier work I have argued that one reason for the extensive repertoire of Rembarrnga sculpture has been the desire of Rembarrnga artists to represent traditional subjects of importance to them and their culture in a way that is safe to show publicly and fibre sculpture is a medium to do so (Keller 2007, p.373f). I have also demonstrated that somewhat more relaxed cultural regulations are applied to sculptural forms than, for example, to bark paintings (Keller 2007, chapter 3 and 7). The rules that apply to bark painting in regards to the depicted subject matter and designs, as 
well as the used cross-hatching and colour sequences, are not as rigorously enforced with sculptural work. Marrkarakara, a Yolngu carver, for example stated that: 'Carvings you don't have to ask anybody, but paintings belong to [individual] people' (Morphy 1977, p. 64). Similarly, fewer restrictions seem to affect Rembarrnga sculpture production. I have shown that rules do apply to sculptural work but that those are certainly not as strict or controlled as in other genres. Rules are mainly applied to ensure the correct execution of designs, forms and mythologies. If such forms have not existed before, as for example, the twined pandanus sculptures, no strict regulations other than general principles of iconicity are applied, that is, the artist's work should be as close as possible to the natural representation of the subject (Keller 2007, p. 378).

Sculptural production among Kuninjku artists can be described along similar lines although their repertoire includes more representations of dreaming sites in sculptural form than embracing expressions of daily life.

As in Central Arnhem Land, with its strong fibre tradition, artists from the Murray River region also have been inspired by their range of traditional fibre products to venture into new forms. Living in Australia's south east where contact with white society and dispossession and dislocation of Aboriginal people occurred at a much earlier date than in the north, the fibre artists' agenda here has been one of highlighting their Aboriginal identity and reclaiming and reinterpreting their cultural heritage.

\subsection{Murray River region}

Aboriginal people living along the Murray River have a long fibre tradition. Many objects of material culture are made of fibre including fish and eel traps, nets, bags and baskets. Missionaries had some influence on the fibre tradition of this region through fostering the coiling technique indigenous to Ngarrindjeri and Yorta Yorta people (West 2007b, p. 13). Ngarrindjeri fibre barely survived in objects collected by national institutions and the knowledge and skills of a few practitioners. It saw a revival in the 1980s and some artists soon 'went sculptural'.

\subsection{Lower Murray River Region (South Australia)}

The first known fibre sculpture from the Murray River region was made by Ngarrindjeri artist Janet Watson in the late 1920s and acquired by the South Australia Museum (SAM) in 1940 (Cubillo-Alberts, Heritage 1995, p.125). For her Airplane, ${ }^{10}$ late 1920 s, she used the coiling technique of the women from the

10 For an image of this sculpture see Kleinert and Neale 2000: 734. 
Kingston region of the lower Murray River. It is made with red coloured sedge grass [Lipospermua canescens] distinctive for fibre work of this region (Sutton et al. 1988, p. 187f).

Watson tailored her coiling technique to produce the irregular shapes of the plane. The sedge bundles are stitched tightly over a wire frame, a technique that was adapted recently by some of the Tjanpi fibre artists from the Central and Western Desert which will be discussed later. The windows of Watson's mono plane are made of celluloid (Kleinert and Neale 2000, p.734f).

The weaving skills from the region were believed to be extinct until Ngarrindjeri elder and artist Doreen Kartinyeri (1935-2007), under the auspices of SAM, initiated a one-day fibre workshop at Meningie in South Australia in 1982. Ellen Trevorrow and Yvonne Koolmatrie were among the workshop attendees from the local Ngarrindjeri community and learned the coiling technique and how to prepare suitable native plant fibres (Perkins et al. 2007, p.276). Both artists were instrumental in the revival of the Ngarrindjeri fibre tradition as they became tireless practitioners and teachers. Trevorrow today instructs Aboriginal and non-Aboriginal visitors to Camp Coorong while Koolmatrie is an arts educator presenting workshops in South Australia and other parts of the country.

Visits to SAM and other collections that hold historic Ngarrindjeri fibre objects including eel and yabby traps, baskets and burial containers helped Koolmatrie to re-establish forms that 'have not been created for almost a century; a sign of the colonial dislocation of Indigenous cultural practices' (Perkins and Kngwarreye 1997, p.12). Koolmatrie also saw Watson's monoplane and was inspired to develop her own sculptural forms including airplanes, hot air balloons as well as other forms and figures based on local species, such as her sculptures of, Murray Cod, Turtle and Echidna (Plate 10), and on Ngarrindjeri lore represented through the River Bunyip, the Rainbow Serpent and Prupi the Child Stealer (Plate11). ${ }^{11}$

In 1997 Koolmatrie's Eel Traps were chosen to be part of the second all Aboriginal art exhibition Fluent shown at the prestigious Venice Biennale representing Australia's cutting edge contemporary art. $^{12}$ In the catalogue Hetti Perkins writes that Koolmatrie's eel traps

have an inherent gracefulness and balance which markedly distinguishes them from other versions. It is Koolmatrie's intuitive process that allows the sculptural potential of the eel trap to be realised in spirited interpretations of traditional forms (Perkins and Kngwarreye 1997, p.12).

The inclusion in Fluent is not only a highlight in Koolmatrie's national and international career as an Aboriginal fibre artist but contributed to the repositioning of Aboriginal fibre art within the international art domain as fine art.

Koolmatrie is, however, not the only artist to reclaim the cultural heritage of Murray River people.

11 Images of the Eel Trap, Turtles, River Bunyip and the Rainbow Serpent can be seen in West 2007a: 20, 94ff.

12 Fluent was curated by Hetti Perkins, Brenda L Croft and Victoria Lynn and included Yvonne Koolmatrie, Judy Watson and Emily Kame Kngwarreye. 


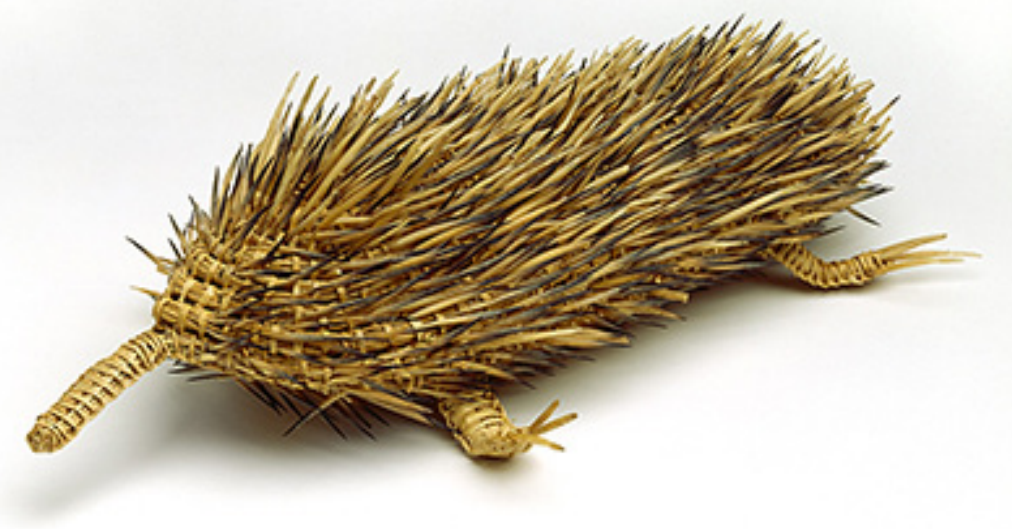

Plate 10: Yvonne Koolmatrie, Echidna, 1999, sedge and echidna quills, 143 x 474 x $283 \mathrm{~mm}$.

Photo: courtesy of National Gallery of Victoria, Melbourne (Yvonne Koolmatrie@), Purchased 1999, NGV \#1999.286).

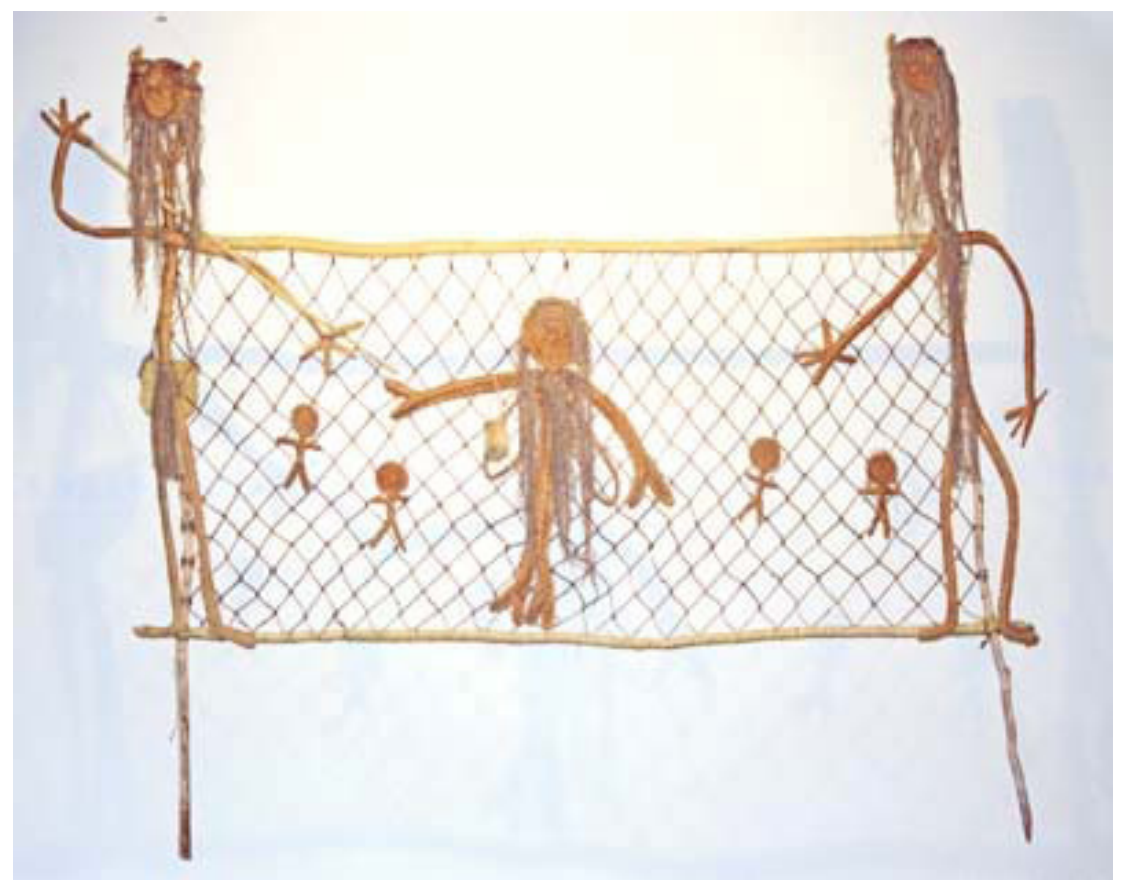

Plate 11: Yvonne Koolmatrie, Prupi - Child Stealer, 1999, sedge grass, malee wood, fibre string from Maningrida, size unknown.

Photo: Yvonne Koolmatrie, courtesy of Yvonne Koolmatrie@ $\odot$. 


\subsection{Upper Murray River Region (Victoria and New South Wales)}

Yorta Yorta artist Treahna Hamm grew up at Yarrawong located on the Murray River in Victoria. She initially established her artistic career in the capital cities along the east coast attending mainstream art schools and mainly working as a print maker. Through contact with Boomalli Aboriginal Artists Co-operative LTD in Sydney she discovered affiliations with the work of other Aboriginal artists. This experience triggered her journey back to her Aboriginal roots and after reconnecting with her mother Hamm started to incorporate Yorta Yorta stories in her work (Croft and National Gallery of Australia 2007, p.101).

In 1999 Hamm was part of a group of artists, including Lee Darroch and Vicki and Debra Couzens, who decided to revive the cloak-making tradition and reproduced the two nineteenth-century possum skin cloaks held by Museum Victoria..$^{13}$ In 2002 Hamm participated in a Melbourne fibre workshop facilitated by Yvonne Koolmatrie and local respected weavers 'Aunty' Dot Peters and 'Aunty' Pat Harrison. This workshop inspired her fibre work with a repertoire of animals and objects. A brilliant example is Hairyman (long legged spirit), 2005 (Plate 12) or Dhungala Gundja - River Home, 2010 (Plate 13). Again, the possibility to work fibre into sculptures allowed her to tell the story of Yorta Yorta history, culture and country in this genre.

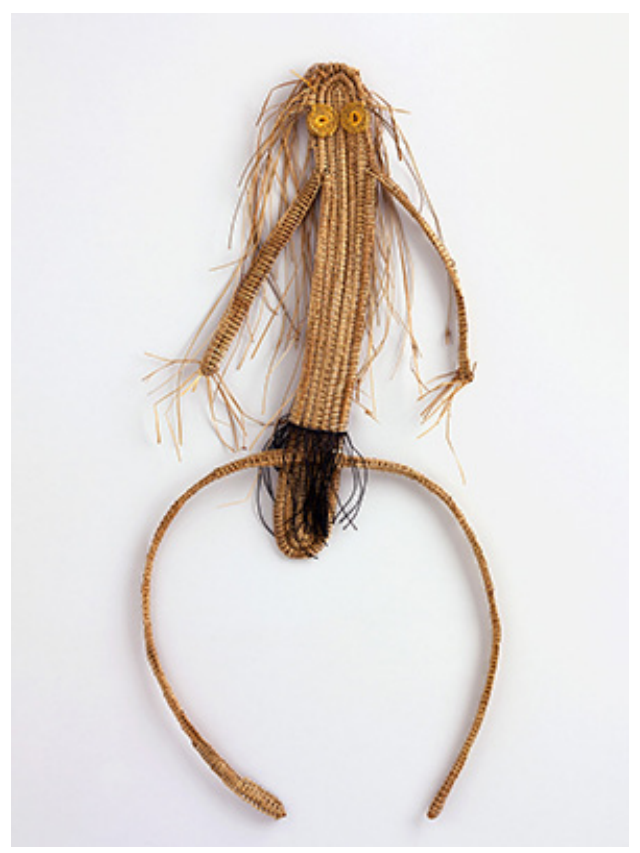

Plate 12: Treahna Hamm, Hairyman (long legged spirit), 2005, sedge, cotton thread, $705 \times 365 \times 380 \mathrm{~mm}$.

Photo: courtesy of National Gallery of Victoria (Treahna Hamm@, Purchased 2005, NGV \# 2005.422).

13 One of the historic cloaks was made by Yorta Yorta people and collected from Maiden's Punt in 1853 (Croft and National Gallery of Australia 2007: 102; Reynolds et al. 2005). 


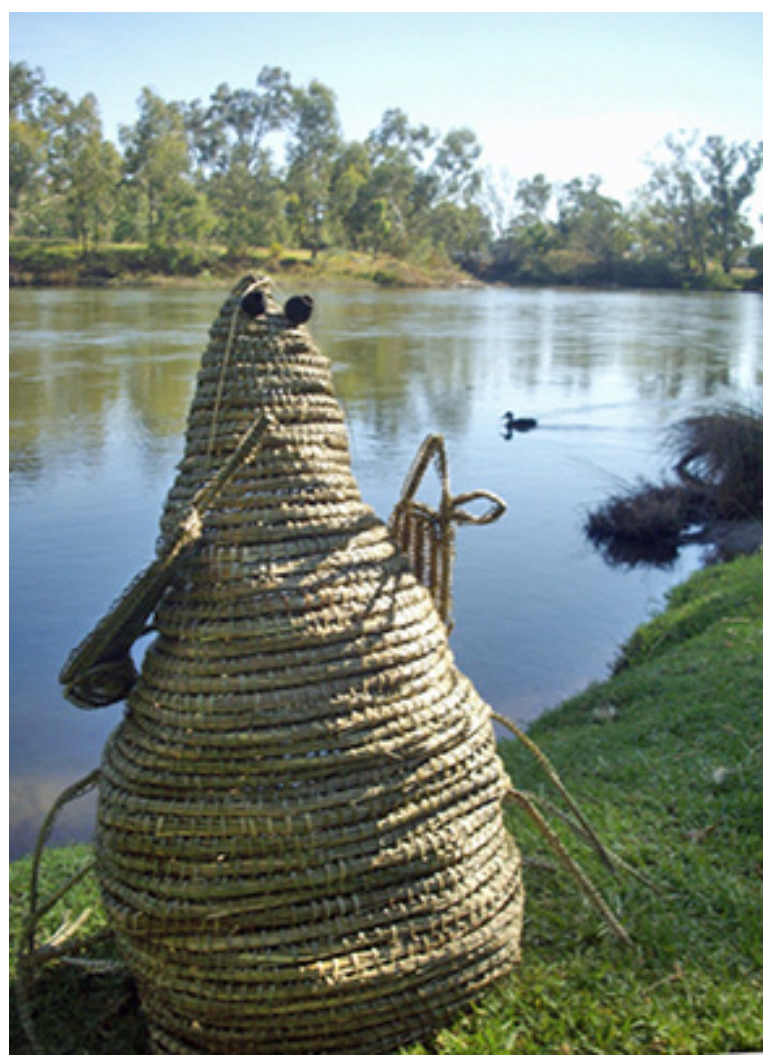

Plate 13: Treahna Hamm, Dhungala Gundja - River Home, 2010, sedge, gumnuts and fishing thread, c. $760 \times 580 \times 300 \mathrm{~mm}$.

Photo: Treahna Hamm, courtesy of Treahna Hamm 0.

Hamm is now living and working in her ancestral homelands of Echuca/Moama/ Barmah along the Murray River, at the border of Victoria and New South Wales and much of her recent works are reinterpretations of traditional items sending the strong message that the connection between Yorta Yorta people and their land is still alive. Hamm also tells stories about the collective experiences of Aboriginal people and teaches history from an Aboriginal point of view.

While Murray River artists revive their fibre tradition, artists in the Central Desert created a new one, the use of tjanpi, literally 'dried grasses' of the region.

\subsection{The Central Desert region}

When in 1995 Thisbe Purich helped set up women's centres across Central Desert communities she introduced coiling to Ana(n)gu women. She realised early on that in comparison to a lot of other art and craft activities introduced in those communities, including pottery, batik, and felting, working with local grasses and other fibres does not require a big infrastructure or a permanent 
work space and, therefore, suited the lifestyle of women. Most of the raw materials are harvested in the country around the communities and are cheap and relatively easy accessible. The fibre materials, works in progress and finished objects are transportable and women can take them on their travels and carry on working whenever time permits. This is one of the reasons why fibre work has spread like a wild fire across many desert communities transmitted along family networks and ceremonial relationships. Fibre artists teach their relatives and friends how to coil a basket or how to crochet a beanie. As Jo Foster has described: 'Making baskets makes sense. Making baskets is about being in the bush, collecting grass, visiting country, hunting, teaching, learning and earning' (Foster and Patterson 2005). Fibre work has developed into a business for Anangu women as they make objects exchangeable for 'money, family favours or obligations' (Purich n.d.).

Anangu people also have a pre-contact fibre tradition producing a range of ceremonial objects involving fibre as well as hair belts, head bands, hair string skirts, grass, bark and feather shoes. The most commonly used fibre techniques are spinning, string making and binding of fibres. Basket making, coiling and cobbling are new to these artists, although objects like the manguri, a donut shaped ring to help carrying pirti, the wooden bowl full of belongings or water, and 'pukati, squashed wads of emu feathers also used as hair bun' (Purich 2004, p.5), have strongly influenced the early Tjanpi baskets. Mary Jackson's grass Basket, 1995 (Plate 14), was started with bundles of grass stitched together with wool and coiled into the oval shaped rim of the manguri. The bottom of the container was retrospectively filled in with patches of grass. This oval shape of the basket also bears strong resemblance to a wooden pirti.

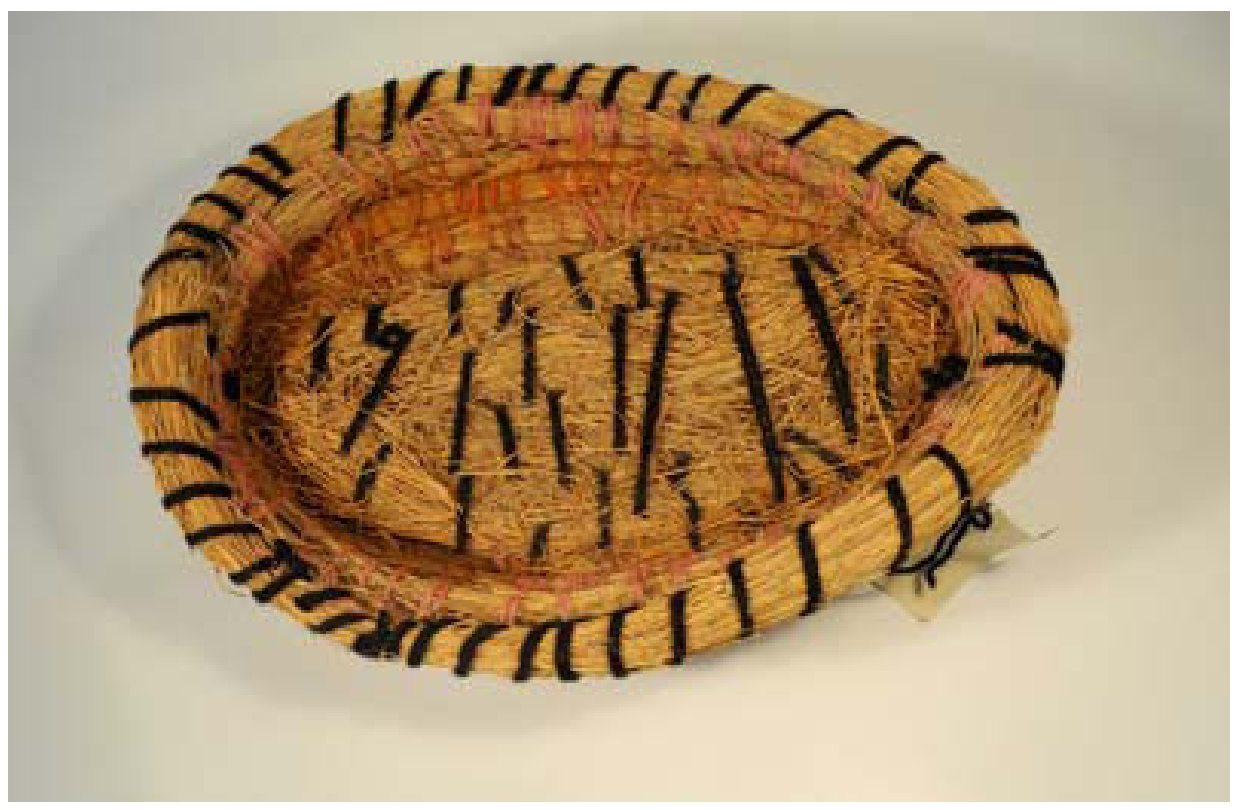

Plate 14: Mary Jackson, Basket, native grasses, wool, 395 x 310 x 125mm. 
Many of the current fibre artists work in a number of media including acrylic painting and purnu carving. ${ }^{14}$ The use of bright, alternating and often contrasting colours reflects the women's painting background and their carving experiences made it easy to make the step from baskets to fibre sculptures.

The first known sculptural fibre object from this region was an emu by Kantjupayi Benson, followed by a dog, and later a set of Camp Crockery, 2001, Plate 15, that featured in the Manguri Weaving touring exhibition in 2001. Benson developed a rather loose coiling or what Nalda Searles, a prolific fibre artist from Western Australia, coined 'cobbling' technique (Nicholls 2007, p.41). Here bundles of grass and other materials are tied and stitched together to create all kinds of shapes and forms. This technique supported Benson's urge to tell traditional stories or scenes from around the camp fire through arranging life-size human and animal figures in narrative sculpture groups. ${ }^{15}$ Once the technique and idea of grass fibre sculptures was established many artists across the region have taken to create their own objects, like Ivy Hopkins with her Wingellina Mail Plane, 2004 (Plate 16).

Fibre work also lends itself to creating projects collaboratively, a feature shared across cultures in Aboriginal Australia. In 2000 the women from Blackstone came together to make a giant two and a half metre high and five metre wide grass basket representing the Anangu weavers at the World Expo in Hannover. Another of these community projects is the life-size Tjanpi Grass Toyota that won the 22cnd NATSIAA in 1995. Toyota four wheel drives are not only prestigious objects in this region but they are particularly valued for providing independence for the owners to facilitate excursions to country and far away family. Money generated through art making often goes towards the purchase of such vehicles.

Collaborations in fibre art occur among Aboriginal artists and across cultures. One of these cross-cultural endeavours is the Seven Sisters, 2003 (Plate 17). The five Desert women involved in the negotiations for the Seven Sisters exhibition invited their mentors Nalda Searles and Thisbe Purich to each make one of the sisters. ${ }^{16}$

14 Purnu are wooden representations of animals or tools decorated with poker work designs.

15 More example of such sculpture groups are Benson's Eagle Story, Wati Kutjara -Two Men, and Bush Banana, all made in 2003, see Ryan 2004: $76 \mathrm{f}$.

16 Images of all Seven Sisters and Wati Nyiru, the larrikin man stalking the seven sisters, are available in Nicholls 2004. 


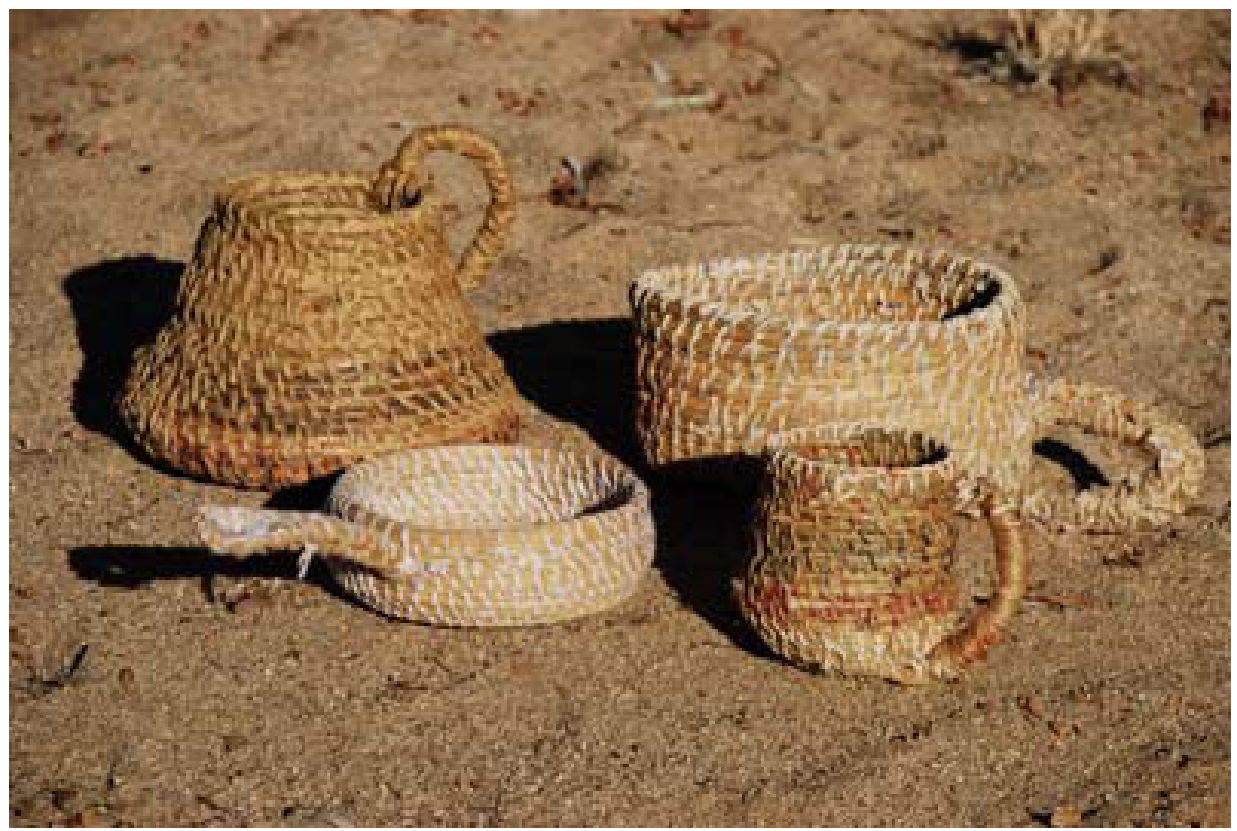

Plate 15: Kantjupayi Bensons, Camp Crockery, 1996, native grasses, string, size unknown

Photo: Stephen Williamson, courtesy of Araluen Gallery (Kantjupayi Bensons@)

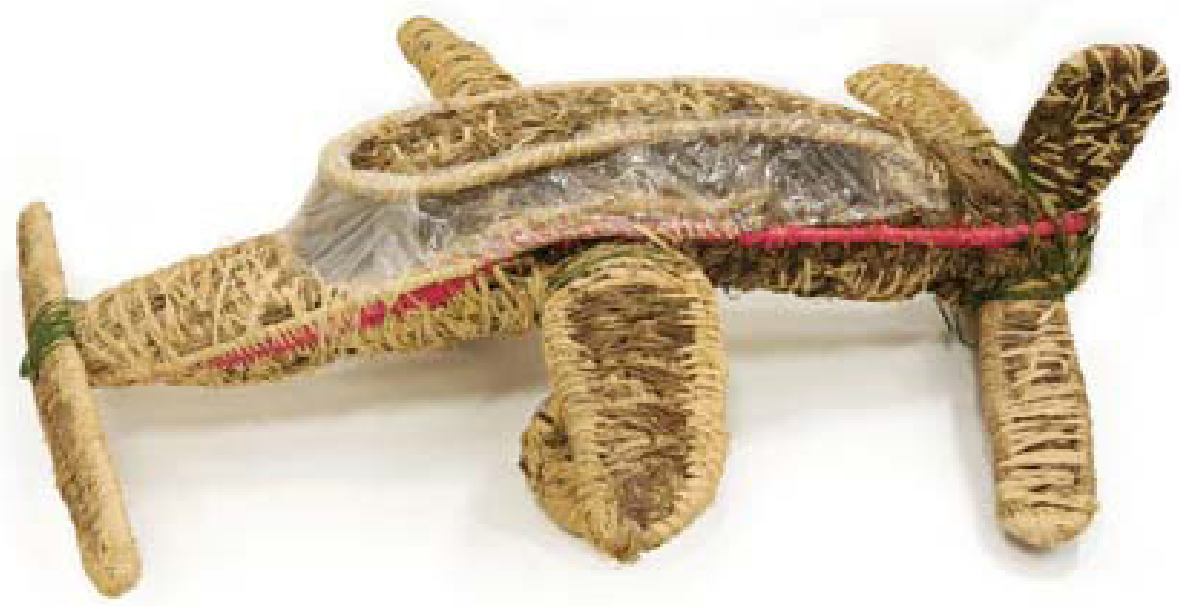

Plate 16: Ivy Hopkins, Wingellina Mail Plane, 2005, native grasses, raffia, string, wool, wood, wire, plastic, $1340 \times 1335 \times 470 \mathrm{~mm}$. 


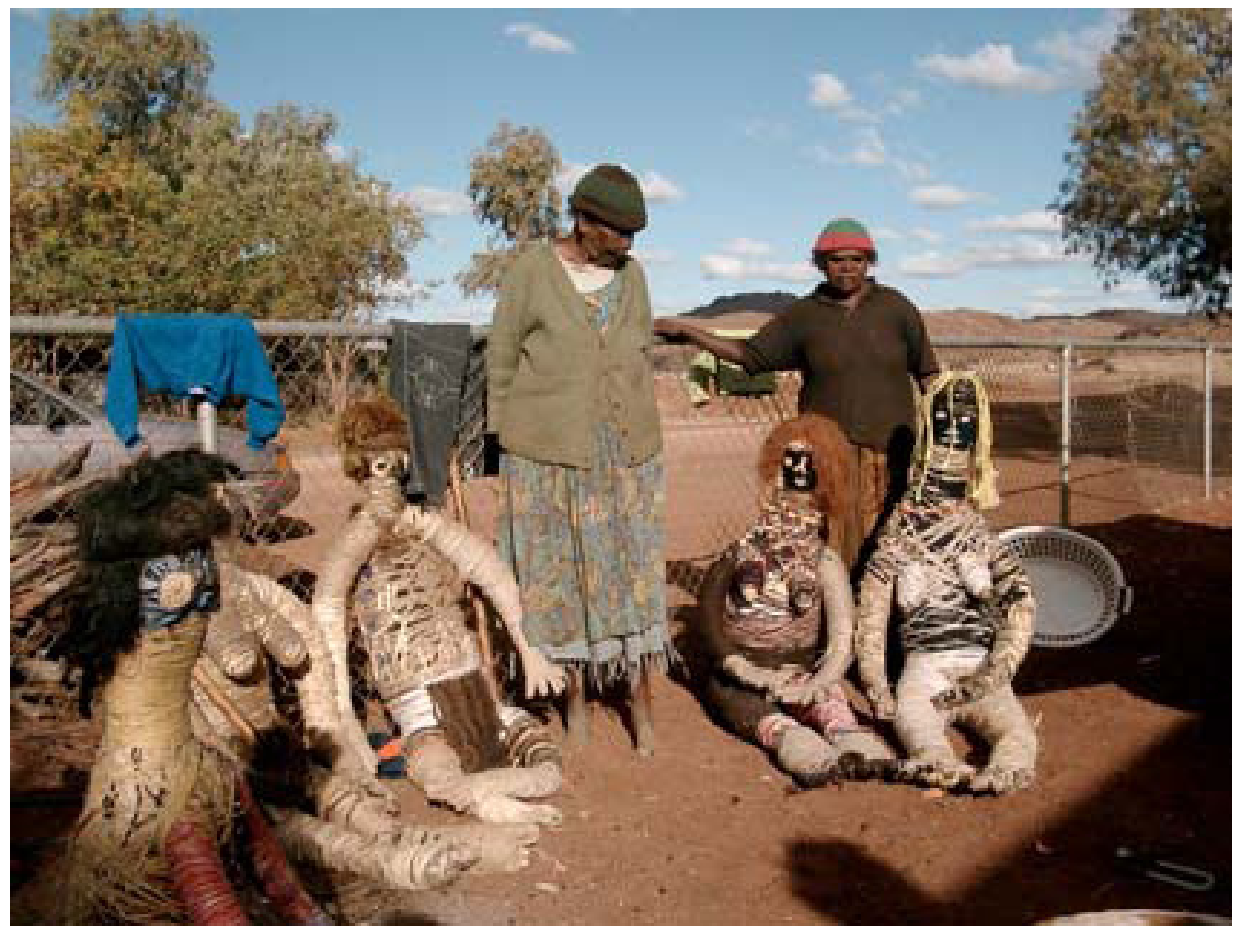

Plate 17: Kantjupayi Bensons, Elaine Lane and five of the Seven Sisters, 2003-04, desert grasses, raffia, string, linen and cotton thread, wool, paper, wire, feathers, human hair, recycled material, life size.

Photo: courtesy of Tjanpi Desert Weavers, (Ivy Hopkins@), Kantjupayi Bensons@), Jean Burke@), Elaine Lane@, WAM \#A26441 - A26446).

In 2001 Steven Anderson and Marina Strocchi from Batchelor Institute of Indigenous Tertiary Education, together with Thisbe Purich from Tjanpi Desert Weavers, started to incorporate fibre sculpture workshops into Batchelor's arts program. Making free- standing grass sculptures is quite a challenge because the material needs to be stabilised enough and worked very carefully so that the sculptures are able to support themselves (Taylor n.d.). The Seven Sisters, for example, not only contain a lot of raw material, they are also very heavy because of it. Therefore, some artists use wire armatures to stabilise their figures from the inside. Working with wire, especially firm and less pliable material needed for life-size figures, also provides a challenge which led to the development of low relief sculptures. Because the sculptures are made 'flat' and are designed to hang on the wall the wire used can be a lot thinner which is easier to work with. According to Jenny Taylor, visual arts lecturer at Batchelor Institute, many fibre artists are also accomplished painters and working with fibre in a two dimensional way seemed to suit. Additionally, the low relief sculpture technique also allowed for freedom of form. 
Animals don't have to stand alone and can be fantastical: dogs can have three legs or five, and long swooping tails, birds can be depicted in full flight, donkeys and camels can have huge rumps and tiny pointy feet, bush tucker shapes can be similar to those painted on canvas (Taylor n.d.).

Taylor has held a series of flat fibre sculpture workshops in Kintore, Nyrripi and other communities around Alice Springs since 2002. The artists made initial drawings of the subject. Then a wire armature was made up based on the drawing. This wire armature was covered with soft chicken wire, then with coiled grass bundles and all layers were firmly stitched together. At Nyrripi a number of women excelled in this technique, among them Dora Napurrula Long, Peggy Napurrula Poulson, Phyllis Napurrula Williams and Topsy Napurrula Fisher. The outstanding work of the latter two artists has been featured in the ReCoil exhibition (West 2007a, pp.80-83). Tjanpi also held a number of workshops and artists sometimes produce flat fibre sculptures, among the most prolific is probably Jean Burke (Plate 18). Siri Omberg, previous art advisor at Titjikala, introduced the idea of flat fibre sculpture to Titjikala artists after she had seen the sculptures at the Batchelor Institute. Here, a number of women have also taken this technique on board.

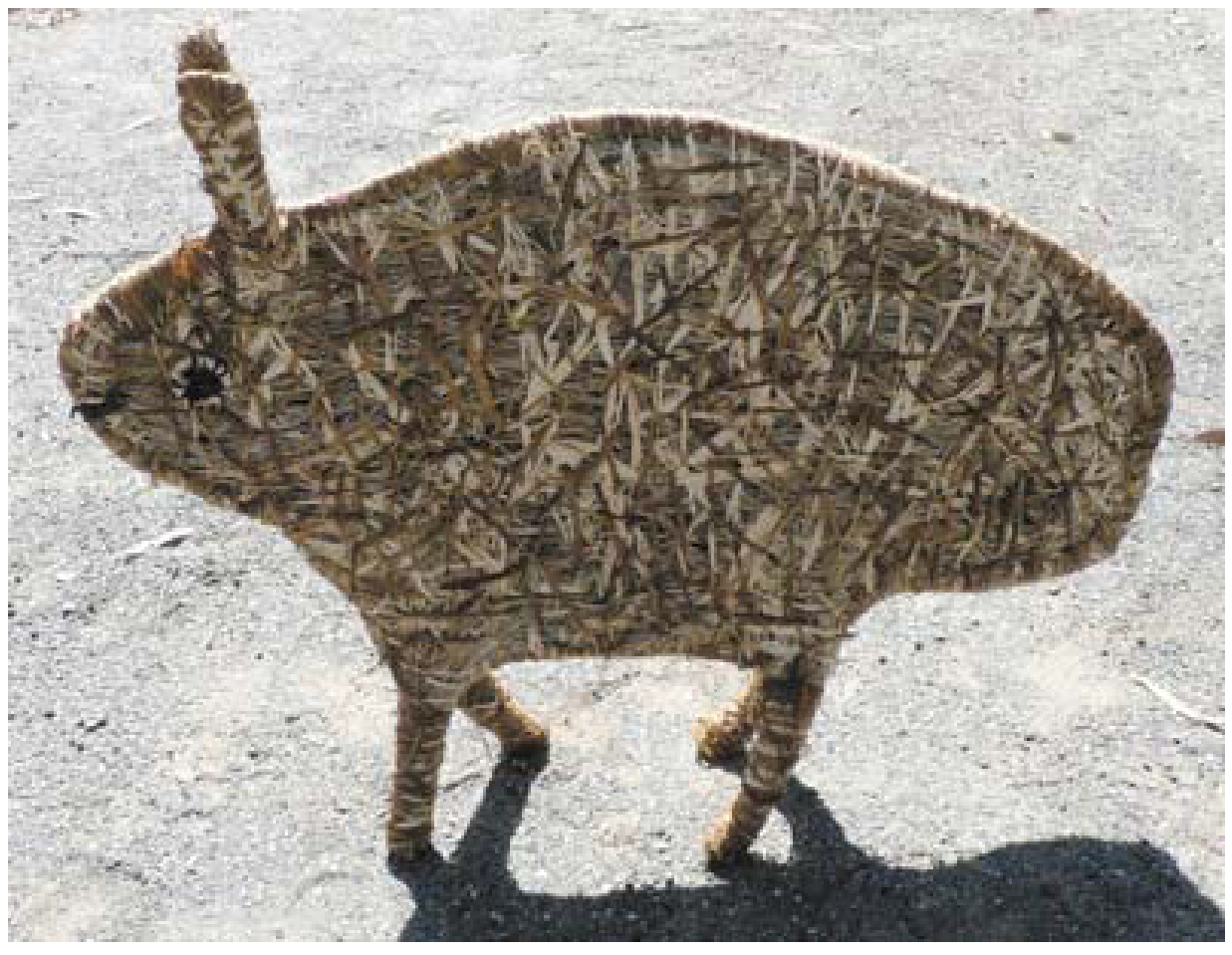

Plate 18: Jean Burke, Possum, 2007, desert grasses, raffia, wire, unknown.

Photo: courtesy of Tjanpi Desert Weavers, (Jean Burke@) 
A central issue with the production of flat fibre sculpture seems to be the rather awkward work with the hard and prickly wire or wire mesh (Jo Foster and Jenny Taylor, pers. comm. June 2009). Many artists do not like working with wire and numerous times the arts teacher or workshop facilitator would collaborate with artists by making the wire armatures, following artists' drawings as faithfully as possible.

An instance of cross-gender and cross-generational collaboration in fibre work occurred in 2008 amongst artists in Utopia. The Utopia Bush Medicine Project was initiated by participants in Batchelor Institute Visual Art and Own Language Work programs, assisted by Jenny Taylor, Margaret Carew and Gail Woods. The project was designed to document and consolidate knowledge about bush medicines used in the Utopia region, and to encourage the involvement of young people in learning about the medicines. In this context of cross-disciplinary workshops, fibre sculpture was seen as one medium amongst several used by people of all ages to explore and translate important cultural concepts into a tangible form, to express and transmit layers of cultural knowledge.

Participants recorded information and stories about plants, methods of gathering and preparing them, and their use as medicines for a range of ailments. Documentation took various forms: sound and video recordings (often made by young people recording their elders), spoken and written language work, drawings, etchings, and fibre sculpture. In one workshop participants made a set of drawings including an inventory of medicinal plants, their preparation and application. The drawings were then used to make 60 mono-print drypoint etchings. One of the etchings by Rosie Kunoth Ngwarray (also known as Kngwarreye) portrayed a narrative of a woman treating her sick daughter with rubbing medicine. This story Awely Anter was recorded and transcribed.

A subsequent workshop introduced flat fibre sculpture techniques. The artists used fibre to represent the various characters of the Awely Anter story (Plate 19). Younger male participants were very interested in working with wire and specialised in fashioning the armatures for the mostly female fibre artists. Then the artists had the idea to animate the fibre sculpture characters to retell the narrative as a stop-animation short film, which was included with five other short films on a DVD. ${ }^{17}$ The exhibition Intem-antey anem: these things will always be, at Araluen Galleries in 2009 featured the fibre works alongside the digital media, text, installations, and etchings about bush medicine (Jenny Taylor, pers. comm. June 2009).

Fibre work and in particular fibre sculpture allows desert women to express their cultural heritage and Aboriginal identity in a medium that suits their lifestyle. It has given them a chance to visit country and allows them to generate income independent from their partners or welfare agencies. Fibre art has become their domain, their voice and a small step in the battle against unemployment, boredom and domestic violence.

17 The DVD is called Intem-antey and is available through the Batchelor Institute. 


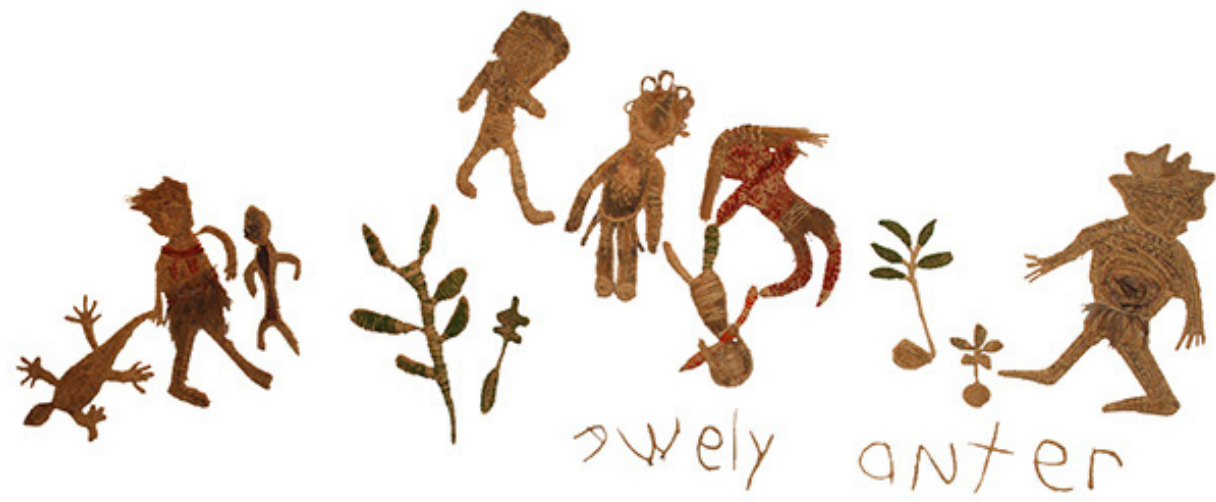

Plate 19: Artists from the Utopia region, Awely Anter, 2008, desert grasses, raffia, wire, various sizes up to $1200 \mathrm{~mm}$.

Photo: Jenny Taylor, courtesy of Jenny Taylor, (Utopia artists@).

\section{Untangling fibre connections}

One of the most astonishing features of fibre art is the nature of sharing, collaboration and mentorship. Throughout the history of Aboriginal fibre artists, arts advisors and curators have worked together to reposition fibre art within the artworld and establish a sustainable market. Learning from each other and the exchange of skills, knowledge and techniques have played vital roles during this journey. It seems, therefore, rewarding to untangle the strands of connection between fibre practitioners.

One of the great exchange stories in Australian fibre art is the spread of coiling across the continent. In Western Australia Mysie Schenk, a missionary from Melbourne, introduced coiling and other fibre techniques to Wongutha women at Mt Margaret Mission in 1923 (Morgan, 1991). Similarly, the Methodist missionary Gretta Matthews learned coiling from Ngarrindjeri women when she worked at an Aboriginal mission near Adelaide and introduced it to the women on Goulbourn Island in 1922 when she continued her mission work in Arnhem Land (West 2007a: 21). Since then the coiling technique has spread along kinship networks and is now to be found all over Arnhem Land and beyond.

Exchanges between artists in workshops and collaborations have also played a great role in the transmission of knowledge and skills. Badtjala artist Fiona Foley with traditional links to Fraser Island started to visit Maningrida in 1986 and helped the arts advisor Diane Moon to organise an exchange of fibre artists from Fraser Island and Maningrida with collaborative fibre workshops in Sydney (Kleinert and Neale, 2000, p.274). Similarly, the workshops at Tandanya Aboriginal Cultural Institute and the exhibition Two Countries, One Weave brought together fibre artists from South Australia and Maningrida in 1991. Here artists realised for the first time their connection through the common coiling technique (West 
2007a, p.21; Kleinert and Neale, 2000, p.372). This initial get-together led to Yvonne Koolmatrie visiting Maningrida in 1994 where she made two turtles from twined and dyed pandanus fibre based on the sister basket technique, originally from Victoria, in which two separately coiled halves are connected to construct the bag's body. ${ }^{18}$ This technique is now used by a number of Arnhem Land artists (West 2007a, p.21). Not only techniques and ideas are exchanged but also materials like the twined bark fibre string used in Koolmatrie's Prupi Child stealer, 1999 (Plate 11) has crossed hands. This string was given to her by Maningrida artists during her visit.

In the same year Arts Tasmania invited Koolmatrie to lead a six-week fibre program in a number of Tasmanian museums and art galleries which led to a strong relationship between Ngarrindjeri and Tasmanian women (DavenportAcker and Webster 2006, p.45) who returned the visit to meet fellow artist Ellen Trevorrow at Camp Coorong in South Australia (Kleinert and Neale 2000, p.374f).

Like all artists introduced in this essay, many other Aboriginal and non-Aboriginal practitioners have also become invaluable teachers and mentors. Artist Nalda Searles encouraged generations of fibre artists in Western Australia and beyond, especially within the move to sculptural forms. Since the early 1980s she has continued teaching fibre techniques in countless cross-cultural workshops. She was instrumental in kick- starting fibre practitioners in Narrogin, Perth, the Pilbara, Carnarvon and also mentors interstate. Similarly, Thisbe Purich was instrumental for the success of the Tjanpi Desert Weavers and other arts educators, like Jo Foster or Jenny Taylor, have contributed to the transmission of techniques and forms. Curators like Diane Moon and Margie West have also had a major influence in creating a sustainable market for fibre art. Moon and West were influential in positioning Aboriginal fibre art in the contemporary fine art market. Similarly, gallerists like Roslyn Premont have been at the forefront of showing new developments within Aboriginal art and fostering new artists and new genres. Premont of Gallery Gondwana (Alice Springs and Sydney) has held several exhibitions featuring newly emerging fibre sculptures from Desert communities. ${ }^{19}$ Pizzi at Gallery Gabrielle Pizzi (Melbourne) was very involved in promoting sculptural work from the Maningrida region and held the first solo show of Lena Yarinkura's fibre sculptures.

\section{Conclusion}

I have shown that in widely separate geographic regions of Australia the move to 'go sculptural' has been successful for a number of reasons. It has brought the ancestral connection of the fibre materials and the related Dreaming stories to the foreground through the representations of the ancestral beings themselves.

18 An image of these two turtles can be seen in West 2007a: 20.

19 To list all exhibitions featuring fibre work at Gallery Gondwana would be too extensive but significant are the shows A Bird in the Hand, 2001, and Kuka, 2002, that introduced the flat fibre sculptures. 
Inventing a new artistic genre has allowed a certain degree of freedom from cultural restrictions enabling women to represent important Dreaming stories. Creating fibre sculptures has fostered cultural identification and reconnection with cultural heritage. It has also become a means to gain some degree of independence for Aboriginal women particularly for those living in remote Australia.

The threads of fibre art reach across the continent and across cultures unlike any other medium in Aboriginal art. One reason might be that it is mainly driven by female artists and art professionals and has led to tangible female empowerment. Ideas, knowledge and skills are passed on from woman to woman. Working with fibre particularly helps Indigenous women to engage with the wider world. Many fibre projects were originally set up for their healing properties to assist the artist to focus and heal loss and addiction by providing a purposeful and fun activity with economic benefits.

Creating a new genre has freed many artists from conventions otherwise restricting their artistic expressions. In fibre sculpture they found a medium to reconnect and reinterpret their cultural heritage and express their cultural identity. The repositioning of fibre art within the wider artworld and the successful creation of a sustainable market for such work allowed fibre artists to continue their work and achieve a reasonable economic return which has helped many of them to become partly or fully independent from government welfare and instil new pride in themselves and their work.

Together the innovative artists, their excellent teachers and mentors and often visionary and tireless curators and gallerists have succeeded in making Aboriginal fibre sculpture into a genre that is as diverse as it is exciting.

\section{Acknowledgments}

I am deeply indebted to the artists for their willingness to talk or write to me about their work and for providing photos for this essay, in particular Lena Yarinkura, Treahna Hamm and Yvonne Koolmatrie. Equally valuable was the help provided to me in form of information and the search for images by Margie West, Nalda Searles, Thisbe Purich, Jo Foster, Alan Fidock and Jenny Taylor. I also would like to acknowledge the Art Gallery of NSW, Milingimbi Arts, Maningrida Arts \& Culture, Tjanpi Desert Weavers, The Western Australian Museum, Araluen Gallery , the National Gallery of Victoria, and the Batchelor Institute for providing images. Invaluable have been comments on earlier drafts by Margie West and Jenny Taylor and the editing work of Moya Smith, Leigh O'Brien and my partner Ludger Dinkler. 


\section{Bibliography}

Alfoldy, S. 2007, NeoCraft: modernity and the crafts. Halifax, NS: Press of the Nova Scotia College of Art and Design.

Berndt, R. M., J. E. Stanton, and University of Western Australia, 1980. Australian Aboriginal art in the Anthropology Museum of the University of Western Australia. Perth: University of Western Australia Press for Anthropology Museum Board of Management University of Western Australia.

Croft, B. L., and National Gallery of Australia, 2007. Culture warriors: National Indigenous Art Triennial. 1st ed. Canberra, ACT: National Gallery of Australia.

Davenport-Acker, C., and M. Webster, 2006. Cultural strands. Perth, WA: FORM Contemporary Craft and Design Inc.

Foster, J., and N. Patterson, 2005. Tjanpi Desert Weavers: Rungkani. In Desert mob: recent work from central Australian Aboriginal art centres, 2006, edited by Araluen Arts Centre, NT: Araluen Centre, 24p.

Keller, C., 2007. Nane Narduk Kunkodjgurlu Namanbom = This Is My Idea. Innovation and Creativity in Contemporary Rembarrnga Sculpture. PhD, Centre for Cross-cultural Research, Australian National University, Canberra.

Kleinert, S., and M. Neale, 2000. The Oxford companion to Aboriginal art and culture. Melbourne: Oxford University Press.

Moon, D., 1993. Maningrida: Tradition im Wandel. In Aratjara - Kunst der ersten Australier: Traditionelle und zeitgenössische Werke der Aborigines und Torres Strait Islanders, edited by B. Lüthi. Düsseldorf: Kunstsammlung NordrheinWestfahlen, 79-81.

Morgan, M. R., 1991. Mt Margaret: a drop in a bucket. Lawson, NSW: Mission Publications of Australia.

Morphy, H., 1977. Marrkarakara: a case study in innovation in Yirrkala art. Australian Institute of Aboriginal Studies Newsletter 7:60-65.

- - - 2005. Seeing Indigenous Australian Art. In Anthropologies of Art, edited by M. Westermann.

Williamstown, MA: Sterling and Francine Clark Institute, 124-142.

,--- 2008 . Becoming art: exploring cross-cultural categories. Sydney: University of New South Wales Press.

Mundine, D., J. Rudder, B. Murphy, and Museum of Contemporary Art (Sydney NSW), 1999. The native born: objects and representations from Ramingining, Arnhem Land. Sydney: Museum of Contemporary Art. 
Myers, F. R., 2002. Painting culture: the making of an aboriginal high art. Durham; London: Duke University Press.

Nicholls, A., 2004. Seven sisters: fibre works arising from the West. Perth, WA: Craftwest.

- - - 2007. Beautiful Mongrels: coiling in the West. In ReCoil: Change and Exchange in Coiled Fibre Art, edited by M. West. Darwin: Artback Northern Territory Arts Touring, 9-46.

Perkins, H., and E. K. Kngwarreye, 1997. Fluent: Emily Kame Kngwarreye, Yvonne Koolmatrie, Judy

Watson: XLVII esposizione internazionale d'arte La Biennale di Venezia 1997, Australian Pavilion, 15 June - 9 November 1997. Sydney: Art Gallery of New South Wales.

Perkins, H., M. West, and Art Gallery of New South Wales, 2007. One sun one moon: Aboriginal art in Australia. Sydney: Art Gallery of New South Wales.

Purich, T. 2004. The Basket Weaving Story Central Australia - How it Started. Ngaanyatjarra Pitjantjatjara Yankunytjatjara Women's Council, unpublished manuscript.

- - - n.d. Story about Manguri, unpublished manuscript.

Reynolds, A. J., D. Couzens, V. L. Couzens, L. Darroch, and T. Hamm, 2005. Wrapped in a possum skin cloak: the Tooloyn Koortakay collection in the National Museum of Australia. Canberra: National Museum of Australia.

Ryan, J., 2004. Colour power: Aboriginal art post 1984: in the collection of the National Gallery of Victoria.

Melbourne: National Gallery of Victoria.

Sutton, P., P. Jones, and S. Hemming, 1988. Survival, Regeneration and Impact. In Dreamings: the art of Aboriginal Australia, edited by P. Sutton, Asia Society Galleries and South Australian Museum. Ringwood, VIC: Viking, 180-212.

Taylor, J. n.d. Batchelor Institute Sculpture Workshops, unpublished manuscript.

West, M. 2000. Telstra presents Transitions: 17 years of the National Aboriginal \& Torres Strait Islander Art Award. Darwin: Museum and Art Gallery of the Northern Territory.

- - - 2007a. ReCoil: Change and Exchange in Coiled Fibre Art. Darwin: Artback Northern Territory Arts Touring.

--- . 2007b. Strings through the heart: A proliferation of coiling across Australia. In ReCoil: Change and Exchange in Coiled Fibre Art, edited by M. West. Darwin: Artback Northern Territory Arts Touring, 13-27. 